\title{
The Influence Of Performance Appraisal Satisfaction On Nurses' Motivation And Their Work Outcomes In Critical Care And Toxicology Units
}

\author{
Nagah Abd El-Fattah Mohamed Aly \\ Nursing Administration \\ Faculty of Nursing, Alexandria University, Matrouh Branch, Egypt \\ Safaa Moustafa El-Shanawany \\ Forensic Medicine and Clinical Toxicology \\ Faculty of Medicine, Alexandria University, Egypt
}

doi: 10.19044/esj.2016.v12n20p119 URL:http://dx.doi.org/10.19044/esj.2016.v12n20p119

\begin{abstract}
:
Nurses' satisfaction with performance appraisal is a critical and important aspect for increasing intrinsic motivation and achieving better work outcomes among nurses. The present study attempted to understand how satisfaction with the performance appraisal process among nurses affects their motivation and their work outcomes as well as to identify the influence of nurses' motivation on nurses' work outcomes. Additionally, it tried to describe obstacles that hinder nurses' satisfaction with performance appraisal process. The study applied cross-sectional descriptive correlation study amongst 323 nurses in Critical Care and Toxicology Units. This study revealed that nurses were dissatisfied with the performance appraisal process and less motivated in their work. Also, their performance and productivity were at fair levels. The present study found that nurses' satisfaction with performance appraisal had a highly significant positive impact on nurses' intrinsic motivation and nurses' work outcomes. This study also indicated that nurses' intrinsic motivation had a highly significant positive relationship with nurses' work outcomes. Additionally, nurses perceived that managerial and organizational forces may hinder their satisfaction with the performance appraisal process.
\end{abstract}

Keywords: Nurses, Satisfaction, Performance Appraisal, Motivation, Work Outcomes

\section{Introduction}

Over the past decades, performance appraisal has been a part of the process of guiding and managing career development in health care sectors 
(Akinbowale et al, 2013). It has become a strategic tool and ubiquitous practice for improving effectiveness and success of health care organizations (Tripathi, 2001; Paul Salau et al, 2014; Puranik and Choudhar, 2014). In hospitals, performance appraisal processes focus on monitoring the performance of healthcare providers, motivating healthcare staff and improving the quality of health care practice and productivity of the staff (Puranik and Choudhar, 2014). Additionally, performance appraisal is considered as a critical important component of human resource function and management because results of performance appraisal are used for managerial decision making and for a variety of other purposes, including employee development, and personnel research (Malik and Aslam, 2013; Puranik and Choudhar, 2014; Josep,2014; Singh and Rana, 2015). The information obtained through performance appraisal provides foundations for recruiting and selecting new hires, training, and development of existing staff, as well as motivating and maintaining a quality workforce by adequately and properly rewarding their performance (Malik and Aslam, 2013; Puranik and Choudhar, 2014).

Performance appraisal includes all the systematic procedures and processes to assess and evaluate individual employee performance and productivity (Jamil and Raja, 2011; Ahmad and Shahzad, 2011; Joseph, 2014; Singh and Rana,2015). It is a method by which the job performance of an employee is evaluated (generally in terms of quality, quantity, cost, and time) typically by the immediate line manager or supervisor (Joseph, 2014). According to Caruth et al (2008) and Khan (2013), performance appraisal is a formally structured system and a continuous process of measuring the inputs and outcomes of every employee with a view to knowing his strengths and weaknesses and discovering how the employee is presently performing in the job. Different terms contribute to performance appraisal as performance evaluation, performance review, personnel rating, merit rating, employee appraisal and employee evaluation (Grub, 2007).

Generally, performance appraisal is a tool that can be used to manage performance effectively, as it provides data which feeds into other elements of the performance management process. If used objectively, performance appraisal can improve motivation, work performance and productivity, but if used inappropriately, it can have disastrous effects (Mullins, 2002; Ojokuku, 2013).

Therefore, the management should pay more attention to the level of employees' satisfaction with the performance appraisal process to achieve employees' motivation which in turn leads to better employee performance and productivity (Malik and Aslam, 2013). The lack of satisfaction with the performance appraisal process in organizations is considered as one of the symptoms of the organizational diseases, so the management should be 
aware of the obstacles that distort employees' satisfaction with the performance appraisal process, take effective measures, and maximize its efforts to overcome these obstacles (Ali et al, 2012).

Across the world, several studies have examined relationships between employees' satisfaction with the performance appraisal process and employees' motivation, their work performance and productivity in different organizations (Ali et al, 2012; Adaeze, 2012; Ojokuku, 2013; Akinbowale et al, 2013; Paul Salau et al, 2014; Joseph, 2014). However, there is a lack of studies that focus on satisfaction with the performance appraisal process among employees working in health care organizations. So, the present study attempted to evaluate the influence of nurses' satisfaction towards performance appraisal process on nurses' intrinsic motivation and work outcome in the form of nurses' work performance and productivity as well as to identify the impact of nurses' motivation on nurses' work outcomes. Furthermore, it tried to identify obstacles that hinder the nurses' satisfaction with the performance appraisal process in the study units.

\section{Material and Methods}

Study Setting: the study setting included 14 critical care and toxicology units within the Alexandria University Hospitals.

Study design: cross-sectional descriptive correlation study

Sample size: 323 nurses who were willing to participate in the study after obtaining informed consent and explaining the purpose of the study to them. Head nurses were excluded.

Data collection: Data were collected by a self -administered questionnaire. It consisted of two parts:

(I) Part A: contained demographic characteristics of critical care and toxicology nurses as age, job title and years of experience in their units.

(II)Part B: contained 32 questionnaires' items regarding nurses' satisfaction with performance appraisal, nurses' motivation, nurses' work performance and nurses' productivity. To ensure the applicability of the studied questionnaire among Egyptian nurses, the researchers established validity and reliability test.

- Content validity: the adopted questionnaire was based on the literature reviews (Cameron and Pierce, 1994; Bekele et al, 2014; Nielsen, 2014) and five experts examined the questionnaire to ensure that the questionnaire scale was complete and easy to follow and that the items 
were not ambiguous. Although the experts had no difficulties in responding to the items, they did suggest some modifications to improve their clarity, which were included in the final questionnaire. The studied questionnaire comprised the following:

(1) Nurses' satisfaction with performance appraisal: the adopted performance appraisal satisfaction scale was developed by Bekele et al (2014), tested for validity and reliability and contained 12 items.

(2) Nurses' intrinsic motivation: the adopted scale was developed by Cameron and Pierce (1994) to measure nurses' intrinsic work motivation. The scale consisted of six items.

(3) Nurses' work outcomes:

- Nurses' work performance: nurses' work performance was measured by using 10 items which were developed by Bekele et al (2014) and tested for validity and reliability

- Nurses' productivity: This scale, which measured self-perception of productivity among nurses in critical care and toxicology units was developed by Nielsen et al (2014) and tested for reliability. There were eight statements, which assess nurses' productivity in their units.

(4) Open-ended question: nurses' opinions about the obstacles that hinder the nurses' satisfaction with the performance appraisal process in their units.

- Construct validity: construct validity was performed by factor analysis. 36 questionnaire items were exposed to a factor analysis using principle component analyses with Varimax rotation. Factor analysis was Eigen values of greater than 1.0 and item loading of greater than 0.50 . Questionnaire items that were less than 0.5 were excluded from factor analysis. The number of questionnaire items was reduced from 36 to 32 as the following (Table $\mathbf{A}$ and B):

- Nurses' performance appraisal satisfaction contained twelve items loaded into two factors and nurses' intrinsic motivation included six items loaded into two factors while nurses' work outcomes in the form of nurses’ work performance comprised nine items loaded into three factors and nurses' work productivity consisted of five items loaded into three factors.

- Loading factors of nurses’ performance appraisal satisfaction, nurses' intrinsic motivation, nurses' work performance, and nurses' work productivity were from 0.592 to $0.988 ; 0.580$ to $0.846,0.622$ to 0.984 and 0.583 to 0.962 respectively.

- The total variance of nurses' performance appraisal satisfaction, nurses’ intrinsic motivation, nurses' work performance, and nurses’ 
work productivity explained by $87.771 \%$; $73.364 \% ; 71.989 \%$ and $74.058 \%$ of the total variance respectively.

- KMO with statistically significant of Bartlett's Test of Sphericity (0.000) for measuring of sampling adequacy were 0.765 for nurses' performance appraisal satisfaction; 0.714 for nurses' intrinsic motivation; 0.668 for nurses' work performance and 0.857 for nurses' work productivity.

- Internal consistency reliability was measured by Cronbach's alpha. The Cronbach's alpha coefficients were 0.892 for nurses' performance appraisal satisfaction; 0.778 for nurses' intrinsic motivation, 0.711 for nurses' work performance and 0.834 for nurses' work productivity (Table A).

- Test - retest reliability: A pilot study was carried out in order to assess the appropriateness of the questionnaire in terms of clarity, comprehensiveness, and difficulties. The questionnaire was distributed among 25 nurses who worked in critical care and toxicology units. The same questionnaire was redistributed to the same 25 nurses after 2 weeks. Pearson correlation was used to assess test- retest reliability. Test -retest reliability was 0.756 .

Nurses rated their response by using a 5-point Likert scale $(1=$ Strongly Disagree, and $5=$ Strongly Agree). Responses of nurses were held anonymous and treated with strict confidentiality. The responses of nurses were analyzed by mean and standard deviation. Mean scores of the questionnaire were classified as the following: $<3=$ fair score, $3-3.9=$ moderate score, $\geq 4=$ high score. This classification was adopted from Bekele et al study in 2014 with a minor modification to be suitable for health care system in Egypt.

Statistical analysis: data were analyzed by SPSS version 18 . The data analysis included the following: (1) descriptive analysis: using frequency and percentage to describe demographic characteristics of nurses (2) Construct validity was tested by factor analysis; (3) Internal consistency reliability was tested by Cronbach's alpha while test- retest reliability was established by Pearson correlation; (4) Correlation analysis was done to identify relationships between nurses satisfaction with performance appraisal and nurses' work outcomes and their motivation. Statistical interrelations / Interrelationships diagram was performed to describe inter- correlations among independent and dependent variables. (5) Regression analysis was applied to identify how much would nurses' performance satisfaction affect nurses' work outcomes and nurses' motivation. 
Table (A): Factor analysis of questionnaire scales

\begin{tabular}{|c|c|c|c|}
\hline Questionnaire items & $\begin{array}{c}\text { Factor } \\
(1)\end{array}$ & $\begin{array}{l}\text { Factor } \\
(2)\end{array}$ & $\begin{array}{l}\text { Factor } \\
\text { (3) }\end{array}$ \\
\hline \multicolumn{4}{|l|}{ Scale (1) : Nurses' satisfaction with performance appraisal : } \\
\hline $\begin{array}{l}\text { I am satisfied with the way the performance appraisal system is used to } \\
\text { evaluate and rate my performance }\end{array}$ & .908 & & \\
\hline Current performance appraisal is fair and unbiased & .981 & & \\
\hline $\begin{array}{l}\text { My head nurse takes my performance appraisal review discussion } \\
\text { seriously }\end{array}$ & .986 & & \\
\hline $\begin{array}{l}\text { Performance appraisal process helps me to find out my performance } \\
\text { level }\end{array}$ & .988 & & \\
\hline $\begin{array}{l}\text { I am satisfied with the way my organization provides me with } \\
\text { feedback }\end{array}$ & .931 & & \\
\hline I do not agree with performance appraisal process & .973 & & \\
\hline $\begin{array}{l}\text { I think that my hospital attempts to conduct performance appraisal the } \\
\text { best possible way }\end{array}$ & .949 & & \\
\hline $\begin{array}{l}\text { My organization seems more engaged in providing positive feedback } \\
\text { for good performers than criticizing the poor ones }\end{array}$ & .979 & & \\
\hline Performance appraisal is valuable to me as well as to my organization & .985 & & \\
\hline The feedback I receive on how I do my job is highly relevant & & .836 & \\
\hline The feedback I receive agrees with what I have actually achieved & & .903 & \\
\hline My organization is good at providing recognition for good performers & & .592 & \\
\hline \multicolumn{4}{|l|}{ Scale( 2) :Nurses’ motivation } \\
\hline The tasks that I do at work are enjoyable & & .765 & \\
\hline My job is so interesting that it is a motivation in itself & & .796 & \\
\hline $\begin{array}{l}\text { The tasks that I do at work are themselves representing a driving } \\
\text { power in my job }\end{array}$ & .763 & & \\
\hline My job is meaningful & .842 & & \\
\hline I feel lucky being paid for a job I like this much & .846 & & \\
\hline The job is like a hobby to me & .580 & & \\
\hline \multicolumn{4}{|l|}{ Scale (3) : Nurses’ work performance : } \\
\hline Often expend extra effort in carrying out my job & .984 & & \\
\hline Try to work as hard as possible & .976 & & \\
\hline The quality of my work is superior & .984 & & \\
\hline Often perform better than what can be expected. & & .960 & \\
\hline Always reach my performance target & & .657 & \\
\hline Feel that my performance is reflective of my abilities & & .960 & \\
\hline $\begin{array}{l}\text { Almost always perform better than what can be characterized as } \\
\text { acceptable performance. }\end{array}$ & & & .622 \\
\hline $\begin{array}{l}\text { Consider my performance is better than the average employee in this } \\
\text { organization }\end{array}$ & & & .807 \\
\hline Overall, I have a very good performance & & & .778 \\
\hline \multicolumn{4}{|l|}{ Scale (4): Nurses’ productivity } \\
\hline Achieve a high level of productivity on the job & .959 & & \\
\hline Make effective use of your time even during “downtime.” & .962 & & \\
\hline accomplish a large amount of work in my unit & .943 & & \\
\hline Work accurately or free from errors & & .583 & \\
\hline Willing to work overtime when asked to do so & & .711 & \\
\hline
\end{tabular}


Table (B): Results of construct validity and internal consistency reliability of questionnaire scales.

\begin{tabular}{|c|c|c|c|c|c|c|c|}
\hline $\begin{array}{c}\text { Questionnaire } \\
\text { scales }\end{array}$ & $\begin{array}{c}\text { No. of } \\
\text { factors }\end{array}$ & $\begin{array}{c}\text { No. } \\
\text { of } \\
\text { items }\end{array}$ & $\begin{array}{c}\text { Factor } \\
\text { loading }\end{array}$ & $\begin{array}{c}\text { Eigen } \\
\text { values }\end{array}$ & $\begin{array}{c}\text { Total \% } \\
\text { Variance } \\
\text { Explained }\end{array}$ & $\begin{array}{c}\text { KMO\& } \\
\text { Bartletts } \\
\text { Test of } \\
\text { sphericity }\end{array}$ & $\begin{array}{c}\text { Cronbach's } \\
\text { Alpha }\end{array}$ \\
\hline $\begin{array}{c}\text { Nurses' satisfaction } \\
\text { with performance } \\
\text { appraisal }\end{array}$ & 2 & 12 & $\begin{array}{c}0.592- \\
0.988\end{array}$ & 1.880 & 87.771 & $0.765(.000)$ & 0.892 \\
\hline $\begin{array}{c}\text { Nurses' motivation } \\
\text { Nurses' work }\end{array}$ & 2 & 6 & $\begin{array}{c}0.580- \\
0.846\end{array}$ & 1.322 & 73.364 & $0.714(.000)$ & 0.778 \\
\hline performance & 9 & $\begin{array}{c}0.6220- \\
0.984\end{array}$ & 1.529 & 71.989 & $0.668(.000)$ & 0.711 \\
\hline Nurses' productivity & 2 & 5 & $\begin{array}{c}0.583- \\
0.962\end{array}$ & 1.174 & 74.058 & $0.857(.000)$ & 0.834 \\
\hline
\end{tabular}

\section{Results}

Table 1 shows critical care and toxicology nurses, according to demographic characteristics. It was revealed that more than half of the nurses (54.2\%) were staff nurses compared to $29.7 \%$ being professional nurses, $16.1 \%$ were technical nurses. Age of the study nurses ranged from 20 years to more than 50 years. $41.4 \%$ of nurses had age between 30 and 39 years while $5.6 \%$ of them had age above 50 years. Half of nurses $(50.1 \%)$ had work experience in their units ranging from 10 to 19 years.

Table 2 reveals the distribution of the nurses' mean score levels regarding their satisfaction with performance appraisal, work outcomes, and motivation. It was shown that the high mean scores were nurses' satisfaction with performance appraisal $(2.88 \pm 0.712)$ followed by their work performance ( $2.65 \pm 0.584)$ and their productivity $(2.64 \pm 0.641)$. The lowest mean scores were nurses' intrinsic motivation (2.37 \pm 0.578$)$.

Table 3 and figure 1 illustrate the effects of performance appraisal satisfaction on work outcomes and motivation among nurses as well as the relation to their motivation with work outcomes. It was revealed that nurses' satisfaction with performance appraisal had a highly significant positive correlation with their motivation $(\mathrm{r}=0.765, \mathrm{P}<0.01)$, their performance $(\mathrm{r}=0.819, \mathrm{P}<0.01)$ and productivity $(\mathrm{r}=0.945, \mathrm{P}<0.01)$. It was also shown that nurses' intrinsic motivation had a high positive correlation with nurses' performance $(\mathrm{r}=0.777, \mathrm{P}<0.01)$ and their productivity $(\mathrm{r}=0.786, \mathrm{P}<0.01)$.

Table 4 and 5 represent regression analysis of nurses' satisfaction, performance appraisal, their motivation, and work outcomes. It was clear that nurses' satisfaction with performance appraisals had a highly significant positive relationship with their motivation (Beta $=0.765, \mathrm{P}<0.01$ ), their performance (Beta $=0.819, \mathrm{P}<0.01$ ) and their productivity (Beta $=0.945, \mathrm{P}$ $<0.01$ ). Also, nurses' motivation had a highly significant positive relationship with their performance (Beta $=0.777, \mathrm{P}<0.01$ ) and their productivity (Beta $=0.786, \mathrm{P}<0.01)$. B value indicated that as the nurses' 
satisfaction with performance appraisal increases, their motivation (0.726), performance (0.749) and productivity also increase (0.970). Additionally, it also indicated that as the nurses' motivation increases, their performance (0.644) and productivity also increase (0.850).

Furthermore, the $R^{2}$ value indicates that performance appraisal contributes to the nurses' intrinsic motivation, performance and productivity by $58.5 \%, 67.1 \%$ and 89.3 respectively. The $R{ }^{2}$ value also indicates that nurses' motivation contributes to the nurses' performance and productivity by $60.4 \%$ and $61.8 \%$ respectively. The results of the regression analysis suggest that the appraisal system strongly influences the nurses' intrinsic motivation $(\mathrm{F}=517.398, \mathrm{P}<0.01)$, nurses' productivity $(\mathrm{F}=747.843, \mathrm{P}<$ $0.01)$ and performance $(\mathrm{F}=3051.559, \mathrm{P}<0.01)$. In the same time, the nurses' motivation also strongly influences the nurses' productivity (F = 559.338, $\mathrm{P}<0.01$ )and nurses’ performance $(\mathrm{F}=591.858, \mathrm{P}<0.01)$.

Table 6 indicates nurses' perceived obstacles that hinder their satisfaction with performance appraisal in Critical Care and Toxicology Units. The table demonstrates that the majority of nurses had the perception that these resistance forces were a lack of performance appraisal feedback (85.4\%), inadequately structured performance appraisal form (82.7\%), using of performance appraisal for constraining the nurses (79.0\%) and rejected performance appraisal policy (77.1\%). Meanwhile, about two - thirds of nurses reported the use of performance appraisal results in punishment (65.6\%) and not in training and development of nursing staff (58.8\%). Furthermore, more than a half of the nurses complained of the unfairness of the performance appraisal process (53.6\%) as well as the reluctance $(52.3 \%)$ and lack of time needed for supervisors to complete the performance appraisal process (51.7\%).

Table (1): Critical Care and Toxicology nurses according to demographic characteristics

\begin{tabular}{|l|r|r|}
\hline \multirow{2}{*}{ Demographic characteristics } & \multicolumn{2}{|c|}{ Critical care \& Toxicology Nurses } \\
\cline { 2 - 3 } & no. & $\%$ \\
\hline Job title & & \\
\hline Professional nurse & 52 & 29.7 \\
\hline Technical nurse & 175 & 16.1 \\
\hline Staff nurse & & 54.2 \\
\hline Age & 112 & 34.7 \\
\hline $20-$ & 134 & 41.4 \\
\hline $30-$ & 59 & 18.3 \\
\hline $40-$ & 18 & 5.6 \\
\hline $50+$ & & \\
\hline Years of experiences in units & 112 & 34.7 \\
\hline$<10$ & 162 & 50.1 \\
\hline $10-$ & 49 & 15.2 \\
\hline $20+$ & & \\
\hline
\end{tabular}


Table (2): Distribution of the nurses' mean score levels regarding their satisfaction with performance appraisal, motivation, and work outcomes.

\begin{tabular}{|l|c|c|}
\hline \multicolumn{1}{|c|}{ Questionnaire scales } & Mean & SD \\
\hline Nurses satisfaction with performance appraisal & 2.88 & 0.712 \\
\hline Nurses' intrinsic motivation & 2.37 & 0.578 \\
\hline Nurses' work outcomes & & \\
\hline Nurses’ work performance & 2.65 & 0.584 \\
\hline Nurses' productivity & 2.64 & 0.641 \\
\hline
\end{tabular}

Table (3): Effects of performance appraisal satisfaction on nurses' work outcomes and their motivation as well as the relationship between nurses' motivation and their work outcomes

\begin{tabular}{|l|c|c|}
\hline $\begin{array}{c}\text { Nurses' motivation \& their work } \\
\text { outcomes }\end{array}$ & $\begin{array}{c}\text { Nurses' satisfaction with } \\
\text { performance appraisal }\end{array}$ & Nurses' motivation \\
\hline Nurses' intrinsic motivation & $0.765\left(^{* *}\right)$ & \\
\hline Nurses’ work outcomes & & $0.777\left(^{* *}\right)$ \\
\hline Nurses’ work performance & $0.819\left(^{* *}\right)$. & $0.786\left(^{* *}\right)$ \\
\hline Nurses' productivity & $0.945\left(^{* *}\right)$. & \\
\hline
\end{tabular}

** Pearson's Correlation (r) is significant at the 0.01 level (2-tailed).

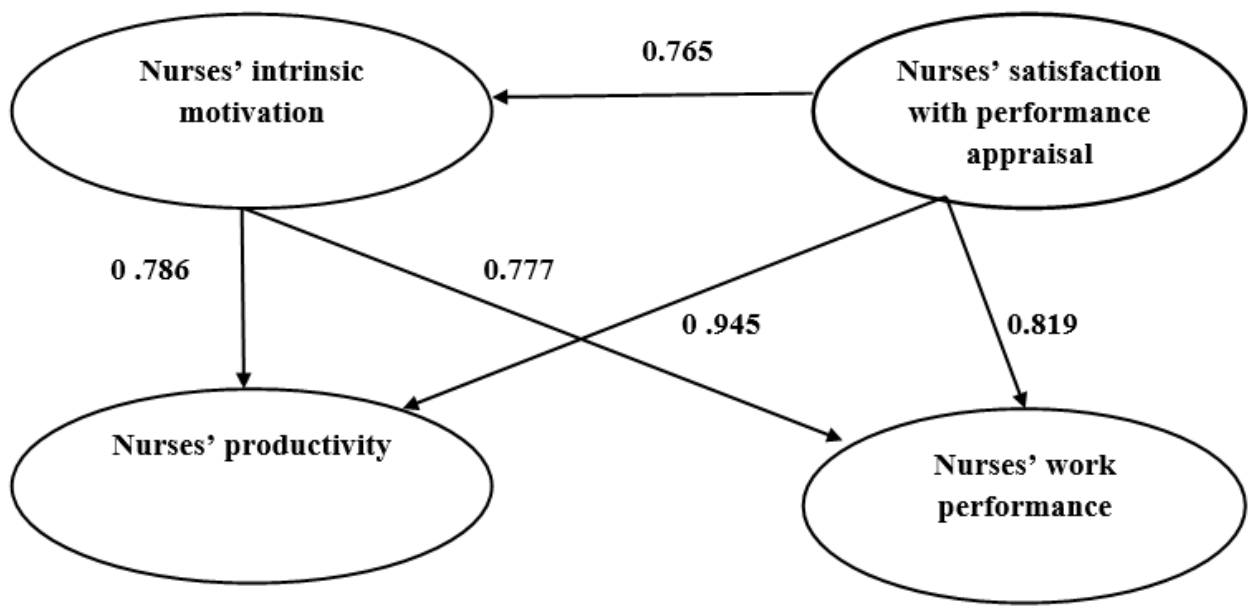

Figure (1): Statistical interrelations diagram amongst Independent and dependent variables 
Table (4): Regression analysis of nurses' satisfaction with performance appraisal, their motivation, and work outcomes.

\begin{tabular}{|c|c|c|c|c|c|c|c|c|c|}
\hline \multirow{2}{*}{$\begin{array}{c}\text { Nurses' } \\
\text { motivation } \\
\begin{array}{c}\text { \& their } \\
\text { work } \\
\text { outcomes }\end{array}\end{array}$} & B & Beta & $\mathrm{T}$ & Sig. & $\mathrm{F}$ & Sig. & $\mathrm{R} 2$ & $\begin{array}{c}\text { Adjusted } \\
\text { R2 }\end{array}$ & $\begin{array}{c}\text { Std. } \\
\text { Error of } \\
\text { Estimates }\end{array}$ \\
\cline { 2 - 9 } \\
$\begin{array}{c}\text { Nurses' } \\
\text { intrinsic } \\
\text { motivation }\end{array}$
\end{tabular}

$\mathrm{P}<0.01$ (significant)

Table (5): Regression analysis of nurses' motivation and their work outcomes

\begin{tabular}{|c|c|c|c|c|c|c|c|c|c|}
\hline \multirow[b]{2}{*}{$\begin{array}{l}\text { Nurses' work } \\
\text { outcomes }\end{array}$} & \multicolumn{9}{|c|}{ Nurses' motivation } \\
\hline & B & Beta & $\mathrm{T}$ & Sig. & $\mathrm{F}$ & Sig. & R2 & $\begin{array}{c}\text { Adjusted } \\
\text { R2 }\end{array}$ & $\begin{array}{c}\text { Std. } \\
\text { Error of } \\
\text { Estimates }\end{array}$ \\
\hline $\begin{array}{l}\text { Nurses' work } \\
\text { performance }\end{array}$ & 0.873 & 0.777 & 23.650 & .000 & 559.338 & .000 & 0.604 & 0.603 & 0.623 \\
\hline $\begin{array}{c}\text { Nurses' } \\
\text { productivity }\end{array}$ & 0.850 & 0.786 & 24.328 & .000 & 591.858 & .000 & 0.618 & 0.617 & 0.613 \\
\hline
\end{tabular}

$\mathrm{P}<0.01$ (significant)

Table 6: Nurses' perceived obstacles that hinder their satisfaction with performance appraisal.

\begin{tabular}{|c|c|c|}
\hline \multirow[t]{2}{*}{ Obstacles } & \multicolumn{2}{|c|}{$\begin{array}{c}\text { Critical Care } \& \\
\text { Toxicology nurses } \\
\text { No. }=323\end{array}$} \\
\hline & Frequency & $\%$ \\
\hline Lack of feedback & 276 & 85.4 \\
\hline Inadequately structured performance appraisal form & 267 & 82.7 \\
\hline Using performance appraisal to constrain nurses & 255 & 79.0 \\
\hline Rejected performance appraisal policy & 249 & 77.1 \\
\hline Exploiting performance appraisal results in punishment & 212 & 65.6 \\
\hline $\begin{array}{l}\text { Neglecting the use of performance appraisal for training and } \\
\text { development }\end{array}$ & 190 & 58.8 \\
\hline Unfairness of performance appraisal process & 173 & 53.6 \\
\hline $\begin{array}{l}\text { Reluctance of the supervisors to complete the performance appraisal } \\
\text { process }\end{array}$ & 169 & 52.3 \\
\hline $\begin{array}{l}\text { Lack of time needed for supervisors to complete the performance } \\
\text { appraisal process }\end{array}$ & 167 & 51.7 \\
\hline
\end{tabular}




\section{Discussion}

Today, health care organizations should improve the performance evaluation process for motivating and encouraging their health care providers to enhance their job performance and productivity rather than just measuring their performance (Ojokuku, 2013). Consequently, this would give the health care organization a struggling power to survive, improve its quality of care and enhance its competitive position in the market (Ali et al, 2012). Satisfaction with the performance appraisal system is important, whereas dissatisfaction with the appraisal process has a negative effect on nurses' motivation, nurses' job performance, and their productivity (Taylor et al, 1995; Vigoda, 2000). The present study attempted to understand how satisfaction with the performance appraisal process among nurses affects their motivation and their work outcomes as well as to identify the influence of nurses' motivation on nurses' work outcomes. Additionally, it tried to describe obstacles that hinder the nurses' satisfaction with the performance appraisal process.

The present study found that the nurses in study units were hardly satisfied with the performance appraisal process and less motivated in their work. Also, it was evident from this study that work performance and productivity among nurses were fair. The level of nurses' satisfaction with the performance appraisal process had a significant direct impact on nurses' motivation, work performance and productivity (Table 3 and 4). The performance appraisal process should be equipped with methods of motivating employees to develop themselves and improve their performance (Kuvaas, 2006; Akinbowale, 2013). Similar results were reported in several studies conducted in Asian and African countries as Pakistan, Iran, Kenya and Nigeria, where the appraisal system strongly influenced intrinsic motivation, productivity and performance among employees (Shahzad et al, 2008; Messah and Kamencu, 2011; Jabeen, 2011 , Ali et al, 2012; Ojokuku, 2013; Paul Salau et al, 2014, Afsharnejad and Maleki, 2014).

The findings of the present study also revealed that nurses' motivation had a greater positive effect on nurses' work performance and their productivity. If there was increasing intrinsic motivation among nurses, this would stimulate an increase of nurses' performance and productivity (Table 3 and 5). Kuvaas (2006) mentioned that motivation was an important element to employee performance and productivity. These results of present study conform to those of a study in Nigeria in 2013 which found a link between motivation and performance thus, employees would perform better when highly motivated (Ojokuku, 2013).

Most of the nurses in different levels of nurses' jobs in the study units stated that increasing their satisfaction with performance appraisal and motivation will increase the level of performance and productivity in the 
hospital. The majority of nurses with different age and experience groups were unsatisfied with the performance appraisal process for several reasons (Table 1 and 6). The nurses in the study units said that their head nurses were only responsible for performing performance appraisal, but did not involve them in the performance appraisal process or discuss the results of the performance appraisal with them. The nurses may have felt that the appraisal discussion would help in motivating or encouraging them for enhancing their performance and productivity. Good feedback system makes the employees have a feeling of involvement in the appraisal system (Paul Salau et al, 2014). The performance appraisal process in the study units was characterized by confidentiality and not disclosure to the nurses. The current study is generally in line with those obtained from a study in Nigeria in 2014 where the appraisal system has been largely characterized by non-disclosure of appraisal results to the rates (Joseph, 2014).

Thus, an effective and suitable evaluation process in the organization should provide necessary feedback to the employees and take action for their motivation. Obviously, such organizations with motivated and energetic employees can respond better to the environmental changes, create improved supervisor-employee communications and meet the needs of clients and consumers of services (Villanova et al , 1993; Edmonstone , 1996 ; Wang and Guthrie , 2004; Ali et al , 2014 ). The nurses in this study said that when nurses received feedback from their head nurses regarding performance appraisal process, they were able to avoid unfavorable evaluation in the future. Hence, performance appraisal feedback would reduce any evaluation hesitation and enhance motivation in performing the job.

The nurses also agreed that if they got regular feedback about the performance appraisal process, it could identify weakness and strength points in their performance. Frequent feedback enables the head nurses to provide more opportunity for the nurses to know how well they are performing a job. It will help nurses understand the actual results of their work activities. They will strive to high motivation which could invariably enhance performance, productivity, and quality of nursing care. This finding was supported by Lee (2005) who recommended that performance appraisal through a good feedback mechanism would help employees to know how they are progressing within the organization and carrying out their duties, tasks, and responsibilities. This feedback can be made available on a daily, weekly or monthly basis. Similar findings were found in a study in 2014 in Iran, which revealed the failure to provide feedback to employees and summary evaluation resulting in employees becoming dissatisfied and reducing performance (Afsharnejad and Maleki, 2014). 
Furthermore, the nurses believed that the results of performance appraisal were considered as an instrument that was put in the hands of their head nurses for cracking down on undesired nurses, punishing them and making them follow refused instructions. In contrast, Mayer and Devis (1999) stated that the performance appraisal should be a structured formal interaction between a subordinate and his/her superior. Moreover, the nurses in the study units preferred performance appraisals to be used for training and developing nursing staff. Similar findings were described in the study of Nigeria in 2013 and 2014 (Ojokuku, 2013; Joseph, 2014).

The nurses also viewed that process of performance appraisal as unfair because it described human qualities and focused on managers' priorities rather than real job performance in addition to letting previous negative nurses' attitudes affect the process of judgment. They also believed that supervisors were reluctant and had a lack of time to objectively evaluate nurses based on their actual performance in working units. According to Folger (1997), the appraisal process can become a source of extreme dissatisfaction when employees believe the system is biased, political, or irrelevant. If performance appraisal fairness is carried out effectively, it can play a significant role in developing the trust of employees on organizational systems (Arbaiy and Suradi, 2007).

Generally, the performance appraisal should be well structured in a manner that identifies deficiencies in the performance (Paul Salau et al; 2014). Jamil et al (2011) argued that performance appraisals need to be designed in such a format that has all the elements and aspects of performance so that it can help to recognize the level of performance of the employees. Thomas et al (1994) also suggested that when an organization desires to increase employees' performance and productivity without adding a significant increase in costs, the performance appraisal fairness has been cited as a way of achieving this goal. Several studies in Asian countries (Pakistan, Malaysia, and India) confirmed these statements and reported that there was a fairness of performance appraisal among the studied employees (Malik and Aslam, 2013; Salleh et al , 2013 ; Singh and Rana , 2015).

Finally, nurses also rejected hospital management policy which connected results of the performance appraisal with their competencies, rewards and recognition or considered it an important part of their promotion to higher hierarchy positions and salary increase in their hospitals. Ojokuku (2013) reported that performance appraisal is very important because it has a lot to do with employees' promotion and salary increase. Moreover, Kampkötter (2014) stated that as performance appraisal is related to outcomes such as bonuses, pay increases or promotions; it is essential to measure individual performance as accurately and precisely as possible. 
Thus, the role of the performance appraisal process in rewarding or punishing employees cannot be denied provided that it is done in an objective and fair manner.

\section{Conclusion}

The findings of the present study proved that the nurses' satisfaction with the performance appraisal process in the study units had a significant strongly positive influence on the nurses' motivation and nurses' work performance and productivity. The intrinsic motivation also had a highly positive significant relationship with nurses' performances and productivity. Therefore, satisfaction with performance appraisal plays a definite role in increasing nurses' motivation and getting better nurses' work performance and productivity in their units.

Moreover , the findings of the present study concluded that there were resistance forces that obstacle nurses' satisfaction with performance appraisal process in study units as lack of feedback, inadequately structured performance appraisal, unfairness of performance appraisal, using performance appraisal to constrain nurses and exploiting performance appraisal results in punishment, neglecting the use of performance appraisal for training and development, nurses' rejection of performance appraisal policy, reluctance and lack of time needed for supervisors to complete the performance appraisal process.

\section{Recommendations}

The nursing managers should direct their efforts to overcome or minimize these obstacles, for increasing nurses' satisfaction with the performance appraisal process and increasing intrinsic motivation thereby achieving better performances and productivity among nurses. Therefore, they should focus on the following:

1. Establish a culture of involvement, and participation of nurses in the performance appraisal process.

2. Establish a well -structured performance appraisal that focuses on measuring actual nurses’ performance.

3. Use the results of performance appraisal in the training of nursing staff and not in nonobjective blaming.

4. Regular awareness of nurses all through the performance appraisal process.

5. Allow nurses to be oriented with their performance appraisal comments and discuss the results clearly with their supervisor.

6. Provide a positive feedback for nurses who are good performers rather than criticizing the poor ones.

7. Adopt fair appraisal practices. 
Further research: we need studies in the future that will be aimed to explore the relationship between nurses' satisfaction with the performance appraisal process and organizational justice.

\section{References}

Adaeze EE. The effect of performance appraisal in an organization. Review of Public Administration and Management. 2012; 1(2): 214-26. Afsharnejad A, Maleki M. Performance appraisals impact on attitudinal outcomes and organizational performance. Mathematics and Computers in Contemporary Science, 2014. Available at URL : http://www.wseas.us/e-library/conferences/2013/Milan/ICMA/ICMA 04.pdf ( Accessed at February, 2015)

Ahmad S, Shahzad K. HRM and employee performance: A case of university teachers of Azad Jammu and Kashmir (AJK) in Pakistan. African Journal of Business Management. 2011; 5(13), 5249-53.

Akinbowale MA, Jinabhai DC, Lourens ME. The impact of performance appraisal policy on employee performance: A case study of guaranty trust bank in Nigeria. Mediterranean Journal of Social Sciences. 2013; 4 (14):677-86.

Ali SB, Mahdi A, Malihe J. The effect of employees' performance appraisal procedure on their intrinsic motivation. International Journal of Academic Research in Business and Social Sciences. 2012; 2 (12): 162-8.

Arbaiy N, Suradi Z. Staff performance appraisal using fuzzy evaluation. International Federation for Information Processing. 2007; 247: 195203.

Bekele AZ, Shigutu AD, Tensay AT. The effect of employees' perception of performance appraisal on their work outcomes. 2014; 2 (1): 137-73.

Cameron J, Pierce WD. Reinforcement, reward, and intrinsic motivation: A meta-analysis. Review of Educational Research. 1994; 64: 363- 423.

Caruth DL, Humphreys JH. Performance appraisal: Essential characteristics for strategic control. Measuring Business Excellence. 2008; 12(3): 24-32.

Edmonstone J. Appraising the state of performance appraisal. Health Manpower Management. 1996; 22 (6): 9-13.

Folger R, Konovsky MA, Cropanzano R. A due process metaphor for performance appraisal: In Staw, B. M. and Cummings, L.L. Research in organizational behavior. Greenwich, CT: JAI Press. 1997; 14, 129-77 Grubb T. Performance appraisal reappraised: It's not all positive. Journal of Human Resources Education. 2007; 1(1):1-22. 
Jabeen M. Impact of performance appraisal on employees motivation. European Journal of Business and Management. 2011; 3 (4): 197 -204. Jamil, B, Raja NS. The impact of compensation, performance evaluation, and promotion practices on government employees performance vs. private employees performance. Interdisciplinary Journal of Contemporary Research in Business. 2011; 3(8), 907-13.

Joseph OB. The effectiveness of performance appraisal as a tool to measure employee productivity in organizations. Journal of Public Administration and Governance .2014; 4 (4): 135-48.

Kampkötter P. Performance appraisals and job satisfaction. German Socio-Economic Panel; 2014. Available at URL : https://www.diw.de/documents/publikationen/73/diw_01.c.470483.de/di w_sp0672.pdf (Accessed at August, 2014)

Khan FM. The role of performance appraisal system on employees motivation. Journal of Business and Management. 2013; 8 (4): 66-83

Kuvaas B. Performance appraisal satisfaction and employee outcomes; Mediating and moderating roles of work motivation. International Journal of Human Resources Management. 2006; 17(3): 504-22.

Lee CD. Rethinking the goals of your performance management system. employment relations today. 2005; 32(3):53 - 60 .

Malik MS, Aslam S. Performance appraisal, and employee's motivation: A comparative analysis of telecom industry of Pakistan. Pakistan Journal of Social Sciences (PJSS). 2013; 33 (1): 179-89.

Mayer CR, Davis HJ. The effect of the performance appraisal system on trust for management: A field quasi-experiment. Journal of Applied Psychology. 1999; 84(10): 123-36.

Messah OI, Kamencu SM. The Effect of performance appraisal systems on employees in Kenya tea development agency: A survey of selected tea factories in Meru County-Kenya.Research. Journal of Finance and Accounting. 2011; 2(3):16-34

Mullins LJ. Management and organizational behavior. 5th Ed.London: Financial Tmes Pitman Publishing; 2002.

Nielsen SK. A multi-source model of perceived organizational support and performance. Journal of Organizational Psychology. 2014; 14(2). 78-92.

Ojokuku RM. Effect of performance appraisal system on motivation and performance of academics in Nigerian public universities. Australian Journal of Business and Management Research. 2013; 3 (3) : 20-8

Paul Salau O, Oludayo FO, Omoniyi OC. Modeling the relationship between performance appraisal and organizational productivity in 
Nigerian public sector. Economics Management Innovation. 2014; 6(2): 2-16.

Puranik S, Choudhar GB. A study on employee performance appraisal in health care. Asian Journal of Management Sciences. 2014; 2 (3): 5964.

Salleh M, Amin A, Muda S, Halim. Fairness of performance appraisal and organizational commitment. Asian Social Science. 2013; 9(2): 1218

Shahzad K, Basir S, Ramay MI. The impact of HR practices on perceived performance of university teachers in Pakistan. International Review of Business Research Papers. 2008; 4(2): 302-15.

Singh P, Rana S. The impact of performance appraisal on organizational commitment of bank employees. International Journal of Science and Research (IJSR). 2015; 4 (4): 2964 - 2967.

Taylor MS, Masterson SS, Renard MK, Harrison JK, Carroll SJ. Due process in performance appraisal: A quasiexperimental in procedural justice. Administrative Science Quarterly. 1995; 40 (3):495-523.

Thomas SL, Bretz RD. Research and practice in performance appraisal: Evaluating performance in America's largest companies. SAM Advanced Management Journal. 1994; 22 (2), 28-37.

Tripathi PC. Personnel management and IR. 1 st ed. New Delhi: Sultan Chand \& sons. 2001; 163-200.

Vigoda E. Organizational politics, job attitudes, and work outcomes: Exploration and implications for the public sector. Journal of Vocational Behavior. 2000; 57 (3): 326-47.

Villanova P, Bernardin HJ, Dahmus S, Sims R. Rater leniency and performance appraisal discomfort. Educational and Psychological Measurement. 1993; 53: 789-99.

Wang JH, Guthrie JT. Modeling the effects of intrinsic motivation, extrinsic motivation, the amount of reading achievement on text comprehension between the US and Chinese students. Reading Research Quarterly. 2004; 39(4), 162-86. 